\title{
Organic Waste in Composting: A brief review
}

\author{
Suhas S. Gonawala ${ }^{\# *}$ and Hemali Jardosh ${ }^{\#}$ \\ \#Civil engineering Department, SCET, Surat, India \\ Received 01 Nov 2017, Accepted 01 Jan 2018, Available online 02 Jan 2018, Vol.8, No.1 (Jan/Feb 2018)
}

\begin{abstract}
This work studied on the composting process of organic waste. Organic waste is the easily biodegradable waste. Organic wastes are produced from many sources Such as agricultural waste, market waste, kitchen waste, urban solid waste and municipal solid waste. Without proper management, this waste could create several environments problem. Therefore, composting is the best low-cost alternative solution to overcome this problem. The composting method can degrade all types of organic waste such as fruits, vegetables, plants, yard waste and others. The organic waste composition can be used as nutrients for crops, soil additives and for environmental management. However, many factors can contribute to the quality of compost products since different types of organic waste have different concentrations of nutrients, Nitrogen, Phosphorus and Potassium $(N, P, K)$ that are the common macro energetics present in fertilizers. The presence of heavy metals shows how Composts can be applied to soils without contributing any negative effects. In terms of the factor affecting the composting process, temperature, $p H$, moisture content and carbon nitrogen ratio ( $C: N$ ) are the main parameters that contribute to the efficiency of the composting process.
\end{abstract}

Keywords: Organic waste, composting, solid waste

\section{Introduction}

Because the large amount of organic waste in the environment has become one of the main global problems. Among the various treatments in the management of organic waste such as the use of landfills and incineration, the decomposition of organic waste through the use of biological processes is considered more appropriate method of solution. Composting is one of the low cost biological decomposition process. The composting process is circuited by microbial activity. The physical-chemical parameters affected by this process include temperature, aeration, and moisture content, $\mathrm{C}: \mathrm{N}$ ratio and $\mathrm{pH}$. Composting is an alternative solid waste management system (SWM), it can be used to recycling of organic materials into useful products. In addition, it can also be used to control the increase in waste. This process is considered the most efficient, environmentally safe and as agronomically as possible, where the compost can be used as a soil conditioner, organic fertilizer also as it contains high nutrients for the soil. The microbial community in compost, which are bacteria, fungi and worms can also stabilize the degradable organic matters. The performance of the composting process also will depend on the

*Corresponding author Suhas S. Gonawala is a M.E. (Environmental Engineering Department) Scholar; ORCID ID: 0000-0001-69475213 and Hemali Jardosh is working as Assistant Professor DOI: https://doi.org/10.14741/ijcet.v8i01.10884 characteristics of the waste because composting is only suitable for waste that is biodegradable. The application of compost can improve the properties of the soil that are badly in need of renewal, as it can increase the organic carbon contents in the soil. In the meantime, compost also acts as a soil intervention to improve soil structure, water infiltration rate, water Retention capacity and tilth.

\section{A. Benefits of composting}

1. Healthier plants.

2. Composting is practical and convenient.

3. Composting saves your money.

4. Composting is a good alternative to land filling.

\section{B. Compost application to agricultural soil}

Composting helps to optimize the management of nutrients and the application of compost on the land can contribute the decrease of soil organic matter and soil erosion. The recycling of compost on the ground is considered as a way to maintain or restore the quality of the soils, mainly due to the fertilizing or improving properties of organic matter. In addition, it can contribute to carbon sequestration and can partially replace the peat and fertilizers. Compost application to agricultural land needs to be carried out in a manner that ensures sustainable development. Management systems must be developed to allow maximize the 
benefit of agronomy, while ensuring the protection of environmental quality. The main determinant for efficient agronomic use is the availability of nitrogen, the high use of nitrogen in mineral agriculture fertilizer is well established and understood, while increasing the nitrogen use; the efficiency of fertilizer requires further investigation.

\section{The composting process}

The composting of agricultural waste and municipal solid waste has a long history and is commonly used to recycle organic matter back into the soil to maintain soil fertility. The recent increase in composting, however, it has been arisen due to the need for an environmentally sound waste treatment technologies. Composting is seen as an environmentally acceptable waste treatment method. It is an aerobic biological process which uses naturally occurring microorganisms to convert biodegradable organic matter into a humus like product. The process destroys pathogens, converts $\mathrm{N}$ from unstable ammonia to stable organic forms, reduces the volume of waste and improves the nature of the waste. It also makes waste easier to handle and transport and often allows for higher application rates because of the more stable, slow release in nature of the $\mathrm{N}$ in compost. The effectiveness of the composting process is influenced by factors such as temperature, oxygen supply (ie, aeration) and humidity content.

\section{Types of composting}

There are two fundamental types of composting aerobic and anaerobic:

\section{Aerobic composting}

Composting is the decomposition of organic waste in the presence of oxygen (air); the process includes $\mathrm{CO}_{2}$, $\mathrm{NH}_{3}$, water and heat. This can be used to treat any type of organic waste but, effective Composting requires the right combination of ingredients and conditions. These include the moisture contents around $60-70 \%$ and Carbon to Nitrogen (C / N) ratios of 30/1. Any significant variation inhibits degradation process. In general, wood and paper provide an important source of carbon, while sewage sludge and food waste provides nitrogen to ensure an adequate supply of oxygen at all times. Ventilation of waste, either forced or passive is essential.

\section{Anaerobic composting}

Anaerobic Composting is the decomposition of organic wastes in the absence of $\mathrm{O}_{2}$, the products being methane $\left(\mathrm{CH}_{4}\right), \mathrm{CO}_{2}, \mathrm{NH}_{3}$ and trace amounts of other gases and organic acids. Anaerobic composting was traditionally used to compost animal manure and human sewage sludge, but recently it is become more common for some municipal solid waste (MSW) and green waste to be treated in this way.

\section{Important Parameters of composting process}

- Water content.

- Nutrients.

- $p H$

- Oxygen Demand.

- Temperature.

- Time.

\section{E. Methods of Composting}

- $\quad$ Static pile

- In-vessel

- Bin Composter

- Windrow

- Vermicomposting

\section{F. Using of Compost}

1. Soil Conditioning

2. Lawn Dressing

3. Vegetable Gardens

4. Flower Gardens

5. Trees and Shrubs

6. House Plants

\section{G. Compost Quality}

Compost quality is measured by several criteria, including the following:

- Moisture Content

- Heavy Metal

- Stability

- Nutrient Content

- Particle Size Distribution

- Pathogen Levels

- Product Consistency over Time

\section{Overview of Organic Waste in Composting}

The composting of organic waste in India is highly encouraged. As a huge amount of wastes are filling our overfilled landfills. Therefore, this paper will review composting as an alternative method for waste management. This paper will review study on how the organic wastes are disposed using the composting method.

\section{A. Classification of organic wastes}

- Agriculture wastes

- Kitchen wastes

- Municipal solid waste

\section{Conclusion}

Composting is a method that respects the environment instead of pouring directly into the soil. It is useful method for converting organic waste into useful 
products that would otherwise have been filled on land. Compost has many benefits such as: reducing landfill space, reducing surface and groundwater contamination, reduce methane emissions, reduce transport costs, reduce air pollution by burning waste, provide a more flexible global waste management, improve the recycling of materials and can be carried out with little capital and operating costs.

\section{References}

Mohammadi Torkashv (2010) Improvement of compost quality by addition of some amendments. AJCS 4(4):252257.

Aeslina Abdul Kadir, Nur Wahidah Azhari and Siti Noratifah Jamaludin (2016) An Overview of Organic Waste in Composting. MATEC Web of Conferences 47.

Anita Kaushal and Umesh Bharti (December, 2015) Microbial Kitchen Waste Composting: Effective Environmentally Sound Alternative of Solid Waste Management. International Journal of Recent Scientific Research Vol. 6, Issue, 12, pp. 7651-7654.

Dhokhikah, Y., \& Trihadiningrum, Y. (2012). Solid waste management in Asian developing countries: challenges and opportunities.
Goswami, L., Nath, A., Sutradhar, S., Bhattacharya, S. S., Kalamdhad, A., Vellingiri, K., \& Kim, K. H. (2017). Application of drum compost and vermicompost to improve soil health, growth, and yield parameters for tomato and cabbage plants. Journal of Environmental Management, 200, 243-252.

Hait, S., \& Tare, V. (2011). Vermistabilization of primary sewage sludge. Bioresource technology, 102(3), 28122820.

K.R. Atalia, D.M. Buha, K.A. Bhavsar, N.K. Shah. A Review on Composting of Municipal Solid Waste. IOSR Journal of Environmental Science, Toxicology and Food Technology. Volume 9, Issue 5 Ver. I (May. 2015), PP 20-29.

Khwairakpam, M., \& Kalamdhad, A. S. (2011). Vermicomposting of vegetable wastes amended with cattle manure. Res J Chem Sci, 1(8), 49-56.

Kosobucki, P., Chmarzynski, A., \& Buszewski, B. (2000). Sewage sludge composting. Polish Journal of Environmental Studies, 9(4), 243-248.

Late, A.M. andMule, M. B. Aerobic Composting of Solid Waste Generated from Aurangabad city (MS), India. Int. J. Environ. Res., 8(2):285-288, Spring 2014.

M. K. Manu, R. Kumar, A. Garg (2015) Drum Composting of Food Waste: A Kinetic Study. International Conference on Solid Waste Management, 5IconSWM.

Mahath. C. S. (2016) Effective Disposal of Sewage Sludge by Composting Method. Imperial Journal of Interdisciplinary Research, 2(6), 97-504. 